\title{
The Polish American narratives, memories and identities in the historian's job
}

Wrocławski Rocznik

The paper is dealing with "personal" sources pertaining to the post-World War II Polish American history. "Personal" is meant here as opposite to "official" (such as minutes, reports, official correspondence), and includes, among others, personal correspondence, personal memos, diaries and memoirs, but also formal and informal interviews and notes from the field from participating observations. What information do those "personal" sources provide that the "official" ones do not? What problems do they bring a researcher? What opportunities do they open up? I do not intend to provide a systematic overview or analysis of this type of sources, but rather to discuss some of their advantages and shortcomings, achievements and perspectives. Nor do I present a complete bibliography. References should be regarded merely as illustrations of the theses discussed.

One of the crucial issues of the Polish American studies not very well reflected in the official documents is the ethnic identity of the Americans of Polish descent. Who is a Polish American? When does an immigrant from Poland, a Pole, become "American"? When does an "American" stop being "Polish"? On the one hand, many of the WWII immigrants regard themselves as Poles and not the Polish Americans, though they have spent 
more time in their life in the United States than in Poland ${ }^{1}$. On the other hand, the fourth, fifth or sixth-generation Polish Americans may completely "forget" their Polish roots or share also other identities, when one of their ancestors may have come from Poland, but others from Bohemia, Germany, Netherlands or other countries ${ }^{2}$; moreover, they may select to show their Polish heritage in one census, but to hide it in another ${ }^{3}$. Some groups or individuals exclude others from the Polish American community, e.g. those who do not take part in any forms of "Polonian" life (organizations, events, reading the Polish American press, attending ceremonies in the Polish American parishes etc. $)^{4}$. On the other hand, people from the "outside" may notice the Polish elements in the everyday life of those who think they have completely Americanized ${ }^{5}$. The language of the "official" documents (Polish or English) may roughly indicate the degree of Americanization of the group they pertain to, but the "private" documents tell us much more.

The question of identity is crucial because the way it is answered determines the scope of the research: whom to include and whom to ignore. For the purpose of my research (and of this article) I accept the widest possible definition, i.e. anyone who has some Polish roots and who spent some time in the United States, from a couple of days to the whole life, and presents his or her American experiences, falls within the scope of my interest ${ }^{6}$. At the same time, one has to be aware that some groups are over-while other are underrepresented in the sources, which distorts the image of the group

1 Comments from the audience of the conference Archiwalia do dziejów polskiej emigracji politycznej z lat 1939-1990, Warsaw, December 3-5, 2014; comments from the audience of the International Women Associates (IWA) of Chicago meeting on May 12, 2014 devoted to Donna Ubrikas' My Sister's Mother.

2 See e.g.: M. P. Erdmans, The Grasinski Girls. The choices they had and the choices they made, Ohio 2004, p. 69-70, 251.

3 See: M. Waters, Ethnic options: Choosing identities in America, Berkeley-Los Angeles-Oxford 1990.

4 K. Hrabyk, Polonia w Stanach Zjednoczonych $i$ w Związku Radzieckim, "Kultura i Społeczeństwo", No. 4 (1970), p. 121-128.

5 Comments from the audience of the Third Tuesday Polish Book Club at the Polish Museum of America, April 14, 2014.

6 On the concept(s) of ethnic identity see: K. Chandra, Constructivist theories of ethnic politics, Oxford 2012, p. 51-177; L. Romanucci-Ross, G. De Vos, T. Takeyuki, Ethnic identity: Problems and prospects for the twenty-first century, Altamira 2006. 
as a whole. Reconstruction of the Polish American past would certainly benefit from enhancing the set of available sources.

There are at least two more "negative" reasons not to ignore "personal" sources in the research of the Polish American past ("negative" means that without these sources the results of the research would bring poorer results). First, the official documents of the Polish American organizations have always been "polished" before publication and tend to omit any controversies. Any issues that could distort the overall positive image of the organization are either completely ignored or summarized in a short statement, such as "the issue has been discussed" us who discussed, how, or what arguments were used. In the Cold War era this technique prevented the intelligence of the communist Poland from getting insight into the internal conflicts and problems of the Polish American ethnic group. Even if the Warsaw regime got minutes of the meetings of the Polish American Congress, which was the case in 1979-1981 ${ }^{8}$, they could learn hardly anything more from them than from the widely available press publications. Today, however, this often prevents historians from deeper understanding of the Polish American realities. I am not sure if the leaders of the PAC had the communist intelligence in mind when implementing those practices or whether they rather cared about the publicity within the American society, especially that the style of the minutes has not changed after 1990 .

Second, and more importantly, many elements of the Polish American life have not been documented on paper at all, especially when we want to go beyond purely organizational matters of the largest Polish American institutions and societies. Many groups did not (and still do not) care about documenting their activities, not to mention problems, dilemmas and choices of individual Polish Americans. Mary Waters noticed a shift from the

7 E.g. "Przewodniczący Komisji Interpelacji del. Gregorek czyta więc raport Komisji i odpowiedzi prezesa Rozmarka, które prezes uzupełnia ustnie ku zupełnemu zadowoleniu Izby." (Delegate Gregorek, head of the Parliamentary Question Committee, reads the Committee's report and Chairman Rozmarek's answers, and Chairman adds his remarks, which is utterly satisfactory to the house."); Protokół trzeciej konwencji Kongresu Polonii Amerykańskiej odbytej w hotelu Chelsea, Atlantic City, N.J. w dniach 30, 31 maja i 1 czerwca 1952, p. 17.

8 They were passed to the Polish intelligence officers by Reinhold Smyczek, director of the PAC from New Jersey. See his personal file: IPN BU o 1824/104. 
studies of ethnic groups towards the studies of individual ethnic identities as better corresponding with the realities of "new ethnicity" of the 1970s and beyond ${ }^{9}$. Many things, big and small, were happening informally, were ephemeral only and have not left any "official" traces ${ }^{10}$. There are places today where the Polish American life flourished in the $19^{\text {th }}$ and $20^{\text {th }}$ centuries, but there was no influx of new immigrants, while the "old Polonia" almost completely Americanized ${ }^{11}$.

Scarcity of the "official" documents seems to be an important factor driving researchers to the "private" documents. They help adopt new research perspectives and new models of historical narratives.

The books by Mary P. Erdmans show the opportunities that "private" sources open to the researcher (and thus show "positive" reasons to refer to them). Opposite Poles is based on the participating observations of the rivalry between established Polish Americans and (relatively) newly arrived Polish immigrants in Chicago in the early 1980s. The Grasinski Girls tells the stories of the third- and fourth-generation Polish American women as presented in the interviews by the author's aunts. Erdmans describes in detail her research methods and presents the difficulties she experienced with collecting and processing data, such as separating being a niece or an activist from being a researcher, taking notes and authorizing manuscript ${ }^{12}$. Both projects were time consuming and emotionally absorbing. Both were not typical in the Polish American scholarship. But both presented invaluable insights into the spheres otherwise beyond the reach of the academic research. In the case of Chicago in the 1980s, the primary sources are extremely biased, as they were created by the activists of the conflicted groups ${ }^{13}$. In the case of the Grasinski sisters, such

9 M. Waters, op. cit., p. 8.

10 K. Ciechorska, Polacy, Polonia, Amerykanie polskiego pochodzenia - "nowa etniczność" młodych przedstawicieli Polonii w Południowej Kalifornii, "Przegląd Polonijny", No. 1-2 (2008), p. 59-73, mentions a mailing list as the only trace left by one of the organizations of young Polish Californians.

11 See: A. Jaroszyńska-Kirchmann, The Polish Hearst: Ameryka-Echo and the Public Role of the Immigrant Press, University of Illinois Press 2015, Epilogue.

12 M. P. Erdmans, op. cit., p. 1-22; M. P. Erdmans, Opposite Poles. Immigrants and Ethnics in Polish Chicago 1976-199o, Pennsylvania State University Press 1998, p. 13-16.

13 The history of one of the conflicting groups, written in A. Jarmakowski, Pomost. W sprawie wolności. 1978-1994, Warszawa 2013, was based on such sources and written by the organization's activist. 
people as Erdmans' aunts: "ordinary", uneducated women taking care of their families, not involved in any organizational life, usually do not leave any sources at all while they, together with their families, constitute the majority of the Polish Americans. What I find as an advantage of Mary Erdmans' works is her positive attitude towards the people and processes she is describing. She seems to accept life as it is and tries to understand people and their motives and appreciate them even if she does not agree or does not want to follow them. There is no nostalgia for the lost "Polishness" in her books. Nor does she give advice or comments on what could have been done better.

Let us now present an overview of the "private" sources useful in the Polish American research.

Private correspondence and memos are located in the archives and in the private collections. Despite the fact that they are often pre-processed by the authors before being deposited in an archive, and some things deliberately are omitted, these sources show us the motives of actions, their background, the perception of certain events and processes. Correspondence and notes by Magnus Kryński, Slavic languages professor of the Duke University, a translator of the poetry of Wisława Szymborska into English, show us his desire to become the main speaker of the Polish American interests at the White House and the Department of State. To achieve this, he aimed at undermining the position of the Polish American Congress in the Washington administration. It seems that this, and not any idealistic motives, was the main reason of his campaign to revoke Yalta in 1984 and the following years ${ }^{14}$.

Analyzing drafts of some official papers can be exhausting, but it may shed light on the nuances that would otherwise remain unnoticed. Handwritten remarks on the margins can tell us more than the documents (e.g. minutes, reports) they are put on. The official documents of the meeting of the Polish American journalists and publishers under the auspices of the Polish American Congress in Chicago on April 30, 1976 only tell us that the participants discussed many important matters, such as the issues of the press in the Polish and in the English language, the advertisement market and the need of its consolidation, the status of the journalists, and plans to run one nation-wide Polish American newspaper. However, the handwritten

14 Connecticut Polish American Archives, Papers of Magnus Kryński, box 4, file 28. 
remarks by Edward Różański, one of the participants, state that there was completely no agreement between the discussants as for the plans for the future and that everyone was against everyone else ${ }^{15}$.

The big problem of the private collections of the Americans of Polish descent is the fact that they are dispersed, not always professionally processed and not very well publicized.

Processing the huge collection of the American Relief for Poland by the Polish Museum of America takes ages, and thus only official minutes are available so far (luckily, the minutes of the monthly meetings seem to be quite accurate as they were not intended to be published). The PMA's collection of Jerzy Przyłuski, one of the most active post-WWII immigrants in Chicago, has never been fully unpacked. Several boxes of documents, notes and correspondence would be invaluable for example for the researchers working on the Polish nationalists in exile. Numerous photographs will become useless unless properly described and as the time passes it will be more and more difficult to find people capable of recognizing individuals, places and events ${ }^{16}$.

There is no central database of the Polish American archival resources. The attempts to create one, undertaken in the late 1990 o by the Polish Institute of Arts and Sciences in America seem to be discontinued. The Polish National Archives include in their databases only the files of the Polish American institutions that they had processed. The Polish researchers are not aware of the mere existence of many American archives that have some papers of the Polish American individuals or organizations ${ }^{17}$. The language barrier is another problem. As a result, many valuable resources have never been taken into consideration by the Polish researchers, especially those dealing with the post-World War II immigrants from Poland ${ }^{18}$.

15 Immigration History Research Center. Papers of Edward and Loda Różański, box 38, folder 1.

16 Visit at the Polish Museum of America, spring 2014. Talks with Małgorzata Kot, Halina Misterka, Jan Loryś.

17 The Institute of National Remembrance has organized two conferences on the archives related to the Polish diaspora in the Cold War era. Archiwalia do dziejów polskiej emigracji politycznej z lat 1939-1990 took place in Warsaw on December 3-5, 2014; Polonica in foreign institutions - research on the history of the Polish political emigration 1939-1990 is scheduled for April 20-22, 2016.

18 Cf. J. Wojdon, Wiesława Piątkowska-Stepaniak, Polska w Nowym Jorku. Idee, spory, nadzieje emigracji politycznej w latach 1940-199o, Opole 2012, review in "Polish American Studies", No. 2 (2013), p. 105-109. 
Diaries, memoirs and other literary works are written with the intention of presenting personal views of their authors. They are widely used by historians, including the historians of the Polish American group. At least five caveats should be kept in mind while planning to work with these sources on the post-WWII history of the Polish ethnic group in the United States.

First, people tend to publish their memoirs (and diaries from the past) when they get old. Therefore it is easier to find diaries and memoirs related to World War II and immediately post-war emigration than to the more recent waves. Younger people often need some form of encouragement. Wiesława Piątkowska-Stepaniak managed to collect written testimonies of the immigrants from the $199 \operatorname{os}^{19}$ and of the Polish American journalists ${ }^{20}$. The former help to question stereotypical images of the troubles that the newly arrived immigrants have to face in America: many of them settled down rather smoothly, sometimes thanks to the assistance of established Polish Americans, and generally enjoy their new lives ${ }^{21}$. The latter bring a lot of details of the difficult period in the history of the Polish American press at the end of the $20^{\text {th }}$ century when it was losing its readership.

Second, authors pay most attention to extraordinary moments of their lives. Therefore, the war experiences of the Polish Americans sometimes dominate in such books; when the war was over, "they lived happily ever after" and the post-war period is either completely missing or only very briefly mentioned ${ }^{22}$. In a similar manner, "important" events and people occupy more space than "regular" friends and everyday life. Kaya Mirecka-Ploss mentions Jan Karski in the very title of her memoirs: Jan Karski człowiek, któremu powiedziałam prawde [Jan Karski - a man whom I've

19 My, emigranci. Wspomnienia wspótczesnych Polaków z życia na obczyźnie, ed. by W. Piątkowska-Stepaniak, Opole 2007.

20 Autoportret zbiorowy. Wspomnienia dziennikarzy polskich na emigracji z lat 19452002, ed. by W. Piątkowska-Stepaniak, Opole 2003.

21 M. Kula, Polskie niepokoje podczas pobytu $w$ Stanach Zjednoczonych odczuwane, “Twórczość”, No. 2 (1991), p. 66-81, supported those observations.

22 E.g. The Mass Deportation of Poles to Siberia: A Historical Narrative based on the written testimony of the Polish Siberian survivors, Siberian Society of USA 20o9; T. Mikosz-Hintzke, A Polish Family's Odyssey, San Jose-New York-Lincoln-Shanghai 2001. 
told the truth $]^{23}$, though most part of her book has absolutely no relation to Karski. The memoirs of Bill Biega and of Jan Krawiec can serve as counterexamples ${ }^{24}$.

Third, strong and especially negative emotions find their way to memoirs easier than the neutral description or positive feelings. Some people seem to write to share (or to cure) their traumas ${ }^{25}$. For Jan Lechoń, a Polish poet who settled down in New York City, writing a journal was a form of prescribed therapy ${ }^{26}$. On the positive side of the scale, Chester Parks' Life in the Old Neighborhood... And Beyond offers a description of the social advancement and Americanization of a second-generation Polish American who grew up in a Chicago Polish neighborhood ${ }^{27}$.

Fourth, some memoirs may adopt other writing genres. Some authors claim to write historical monographs but in fact these are their memoirs, though some primary sources have been used to compile them. Personal views and experiences dominate in those books, however. There is some agenda behind the narrative (e.g. promoting the role and achievements of the author or promoting their organization versus others). The existing historiography is usually ignored, and so is the critical attitude towards the sources. The case of Władysław Zachariasiewicz and his Etos niepodległościowy Polonii amerykańskiej ${ }^{28}$ can serve as an example. The author (104 years old today), a distinguished Polish American activist of various organizations and institutions, presents the endeavors that he participated in during his long life, claiming that it is the first book on the post-WWII Polish American history (which is not).

Autobiographical elements and insights into the Polish American realities from the past can be found in the Polish American literary fiction. The books by Anthony Bukoski should be mentioned as the most recent

23 K. Mirecka-Ploss, Jan Karski - człowiek, któremu powiedziałam prawdę, Katowice 2014 .

24 B. Biega, Thirteen is my lucky number: The dramatic true story of a WWII Polish resistance fighter who became a successful American businessman, Plainsboro 1996;

J. Krawiec, Od Bachórca do Chicago. Wspomnienia, Warszawa 2015.

25 See e.g.: E. Jesko, The Polish American, Lincoln (Nebraska) 2007.

26 J. Lechoń, Dziennik, Poznań 1992.

27 Ch. Parks, Life in the Old Neighborhood... And Beyond, The Mystic Publishers 2006 (Kindle edition 2012).

W. Zachariasiewicz, Etos niepodległościowy Polonii amerykańskiej, Warszawa 2005. 
examples of this genre ${ }^{29}$. Analyzing these works requires methodology of literary rather than historical studies.

Another interpretative difficulty arises when the authors of memoirs incorporate secondary literature into their own narratives. While editing memoirs of Jan Krawiec, a Polish American journalist and activist from the Chicago area ${ }^{30}$, I was able to locate in his manuscript long excerpts from my own book on the history of the Polish American Congress that had been published in $2008^{31}$, but also fragments of Etos niepodległościowy by Zachariasiewicz - without any bibliographical references. Of course, I could be proud of the fact that I was able to reconstruct the past in a way that a participant regards it as his memoirs. But are these really his memoirs? What is the author's "own" in the book? And what about the works that I am not familiar with and therefore could not identify?

Interviews - oral history. A major Polish American oral history project was undertaken in 1976-1977 in Chicago by Mary Cygan thanks to federal funds available for ethnic studies at that time. It concentrated on the then-retiring generation of the economic migrants from the turn of the $2 \mathrm{O}^{\text {th }}$ century. Altogether 140 Chicagoans of Polish descent who arrived in America between 1880 and 1930 were interviewed and 350 hours of testimonies were recorded, dealing mostly with the issues of the interviewees' adaptation to the American society. Thoroughly following the methodology of oral history, the interviews were recorded, transcribed and then deposited in the Chicago History Museum, with copies made for the Loyola University and the Polish Museum in Chicago. The files contain biographical data of the interviewees, index cards, signed release forms, transcripts and recordings. Thematic tapes were prepared dealing with specific issues: early weeks in America, family life, life in the old country, passage and arrival, reasons for deciding to leave, recreation, religion, weddings, women and work. Teacher's Guide for using Oral History Materials on the Immigrant

29 E.g. A. Bukoski, Twelve below zero, St Paul 1986; idem, Children of Strangers, Dallas 1993; idem, North of the Port, Dallas 2008; idem, Time between trains, Duluth 2011.

30 J. Krawiec, op. cit.

31 J. Wojdon, W jedności siła. Kongres Polonii Amerykańskiej w latach 1968-1988, Toruń 2008. 
Experience was also developed ${ }^{32}$. The list of interviewees starts with bishop Alfred Adamowicz, and includes both well-known Polish American activists, such as Sabina Logisz - a long-term librarian at the Polish Museum of America, as well as file-and-rank members of the Chicago Polonia. Despite the fact that the collection is almost forty years old, it is still used by the researchers today, most recently by Megan E. Geigner in her article on the Polish American theater in Chicago in the WWI years ${ }^{33}$.

Today, new generations of Polish Americans can be approached and new research questions asked. The Grasinski Girls sets one path of inquiry: on the Americanized generations of "old Polonia". I interviewed three Polish American women of the second generation (born into the immigrant families) who presented the problems they had to face as children and teenagers (mother tongue, name, customs), the choices they made and the benefits they enjoy in their adult life $\mathrm{e}^{34}$.

Another path of research can be everyday problems of new immigrants of the post-WWII, and especially the post-196o, period. A set of interviews from the 1980 s with the former "Solidarity" trade union members who settled down in America was published in the book Region USA by Andrzej Krajewski in 1989. The interviews are rather journalistic than historical in character, however. Due to the time when the book was published, it could only cover the initial period of the sojourn of the "Solidarity" immigrants in the United States ${ }^{35}$. The same period is presented in the collection of ten interviews with the representatives of the "Solidarity" immigration wave in Ann Arbor, Michigan, carried out in 1989 by Karen Majewski. She used the methodology of oral history and deposited both tape recordings and scripts (more or less accurate) at the Connecticut Polish American Archives.

32 M. Daniels, Oral History Archives of Chicago Polonia (Project) records, 1976-1977. Descriptive Inventory for the Collection at the Chicago History Museum, http://chsmedia.org/media/fa/fa/M-O/OHACP-inv.htm (accessed December 12, 2015).

33 M. E. Geigner, Performing the Polish-American Patriot: Civic Performance and Hyphenated Identity in World War I Chicago, "Theatre History Studies", Vol. 34, No. 1 (2015), p. $59-78$.

34 The paper based on these interviews was presented during the annual meeting of the Polish American Historical Association in Atlanta in January, 2016, and one of the interviews, with Christine Przybyła-Long, is published in this issue of "Wrocławski Rocznik Historii Mówionej".

35 A. Krajewski, Region USA: Działacze "Solidarności" o kraju, o emigracji, o sobie, London 1989. 
In 2015 Anna Reczyńska from the Jagiellonian University applied for

a grant to collect testimonies from the "Solidarity" immigration wave in the United States and Canada, but her application was rejected. There is some interest in the "Solidarity" migrants at the Institute of National Remembrance. It is crucial to interview these while they are still active. It would be also interesting to record the testimonies of the "silent" immigration from the Peoples' Republic of Poland of the 196os and 1970s. People are willing to talk. There are no institutions, neither in the United States nor in Poland, willing to engage in such projects, however.

\section{Participating observations - notes from the field}

Participating observation belongs to the methodology of social studies rather than of history. When applied to the research on the Polish Americans, such as Everyday Life and Festivity in a Local Ethnic Community: Polish-Americans in South Bend, Indiana by Janusz Mucha (Boulder 1996) and Our Way: Family, Parish, and Neighborhood in a Polish-American Community by Paul Wrobel (Notre Dame 1979), it benefits from historical findings in presenting background, "setting up the scenery", but at the same time brings valuable data on the Polish American communities at the time of the research, which has become history by now. Reactions to Paul Wrobel's book show how difficult it may be to present researcher's findings to a larger Polish American community who is not very much open to criticism $^{36}$.

I have never used participating observation as a dominating research method, but observations of the Polish American life, mostly in Chicago in 2014, did broaden my understanding of this group and its subgroups, of various Polish American identities and perspectives, which is reflected, among others, in the footnotes for this article. I could understand, for example, that participants of the PAC meetings could have been annoyed that they were not given opportunity to ask their president questions, while there was time for lengthy speeches of "important" persons, and, on the other hand, that the participants of the $3^{\text {rd }}$ of May parade could be "proud to be Polish". I appreciate the endurance of the participants of WWII and their care of so many people and issues, as well as the efforts needed to organize any Polish American event. At the same time I have a feeling that

36 P. Taras, A. Pienkos, T. Radzialowski, Paul Wrobel's Our Way - Three Views, "Polish American Studies", Vol. 37, No. 1 (Spring, 1980), p. 32-51. 
78 I managed to take part only in a tiny part of what did actually happen during the six months that I spent in the Windy City. I do not think it would ever be possible to decide that the research using the participating observation is complete.

One can complain about the scarcity of "official" documents reflecting the Polish American life. "Private" sources may help but cannot solve all the problems. Moreover, they create their own. They are even more dispersed, distorted, fragmented and incomplete than the official documents. On the other hand, they reflect more nuances, bring more perspectives and more color to the image of the Polish Americans in the second half of the $2 \mathrm{O}^{\text {th }}$ century. Still, they do not guarantee to reconstruct the Polish American history to exactly reflect the reality. After several years of my research on the post-WWII Polish American history I can say there are still more questions than answers. 
The article concerns different kinds of "personal" (in contrast to "official") sources used by historians dealing with the post-World War II Polish American history. The Author considers advantages and shortcomings of analyzing personal correspondence, personal memos, diaries and memoirs, formal and informal interviews and other oral testimonies, but also difficulties and problems they bring to a researcher. Studying those types of source is however often crucial in the absence of official archival documents reflecting e.g. the ethnic identity of the large group of the Americans of Polish descent, or the backstage of the process of their assimilation and organization in the United States.
Joanna Wojdon

The Polish American narratives, memories and identities in the historian's job 